\title{
Accounting in Marketing Perspective Training Batch III, Sekolah Bisnis dan Manajemen - Institut Teknologi Bandung (Sbm-Itb)
}

\author{
Wiwiek Mardawiyah Daryanto \\ Sekolah Tinggi Manajemen IPMI, DKI Jakarta12750, Indonesia \\ Author E-mail: wiwiek.daryanto@ipmi.ac.id
}

\begin{abstract}
A B S T R A K
Akuntansi Manajerial merupakan kegiatan atau proses yang menghasilkan informasi dalam yang bermanfaat bagi manajemen untuk pengambilan keputusan ekonomi dalam menjalankan fungsifungsi manajemen. Sekolah Binis dan Manajemen - Institut Teknologi Bandung (SBM-ITB) berkolaborasi dengan MarkPlus Institute melaksanakan OMNI MBA Program 2020 Batch III pada 5 Februari 2021. Dari dua belas topik mata kuliah yang dalam programnya, salah satunya berjudul Akuntansi dalam Perspektif Pemasaran, dan dijadwalkan pada Jum'at, 5 Februari 2021 dengan penulis sebagai fasilitatornya. Subyek yang diajarkan meliputi teori Break-Even Point (BEP), teori Klasifikasi Biaya dengan konsep Different Cost for Different Puposes, dan studi kasus yang sesuai dengan teorinya. Pelatihan ini diharapkan dapat meningkatkan kompetensi dan produktivitas manajer perusahaan dalam memaksimalkan perannya. Pelatihan ini berjalan lancar karena antusiasme yang kuat dari para peserta didik. Sedangkan, faktor penghambatnya adalah keterbatasan waktu pelatihan.
\end{abstract}

Kata Kunci: Akuntansi Manajerial, Pemasaran, Break-Even Point, Klasifikasi Biaya, Studi Kasus.

A B S T R A C T

Managerial accounting is an activity or process that produces information that is useful for management for making economic decisions in carrying out management functions. Sekolah Binis dan Manajemen Institut Teknologi Bandung (SBM-ITB) collaborated with the MarkPlus Institute to carry out the OMNI MBA Program 2020 Batch III on February 5, 2021. Out of the twelve subject topics contained in the program, one of them is entitled Accounting in Marketing Perspective that scheduled on Friday, 5 February 2021 with the author as the facilitator. The subjects include the Break-Even Point (BEP) theory, the Cost Classifications theory with the concept of Different Cost for Different Purposes, as well as related case studies. This training is expected to increase the competence and productivity of company managers in maximizing their role. This training went smoothly because of the strong enthusiasm of the participants. In addition, the inhibiting factor is the limited training time.

Key word: Managerial Accounting, Marketing, Break-Even Point, Cost Classification, Case Study. 
Copyright (@ 2021 Authors. This is an open access article distributed under the Creative Commons Attribution License, which permits unrestricted use, distribution, and reproduction in any medium, provided the original work is properly cited.

\section{INTRODUCTION}

A manager is someone who has good experience, knowledge and skills recognized by the organization to be able to lead, manage, control, organize, and develop the organization in order to achieve company's goals. According to Hasibuan, M (2011), managers are the main resource and the central point of every activity that occurs in a company. Managers must prioritize duties, responsibilities, and foster harmonious relationships with superiors and subordinates.

Managers are person who have great responsibility to lead all divisions in the company or organization, thus, they shoud have broad insight. Manager plays important roles that determine the success of achieving the goals that have been set to be realized together. There are many roles that managers must play in a balanced manner so that the right people are needed to carry out these roles.

Observing the importance of the role of managers for companies, Sekolah Bisnis dan ManajemenInstitut Teknologi Bandung (SBM-ITB) is collaborating with the MarkPlus Institute held the OMNI 2021 MBA Program Batch III on February 5, 2021. Out of the twelve courses in the program, one of them is entitled Accounting in Marketing Perspective which is scheduled for Friday, February 5, 2021 with the author as the facilitator depicts in Picture 1.

The participants in this training are managers and directors from various companies in Indonesia. These participants have been selected by the Sekolah Bisnis dan Manajemen - Institut Teknologi Bandung (SBM-ITB) and Mark Plus Institute as coordinators of this training program.

\section{Managerial Accounting}

Managerial accounting is an activity or process that produces information based on management

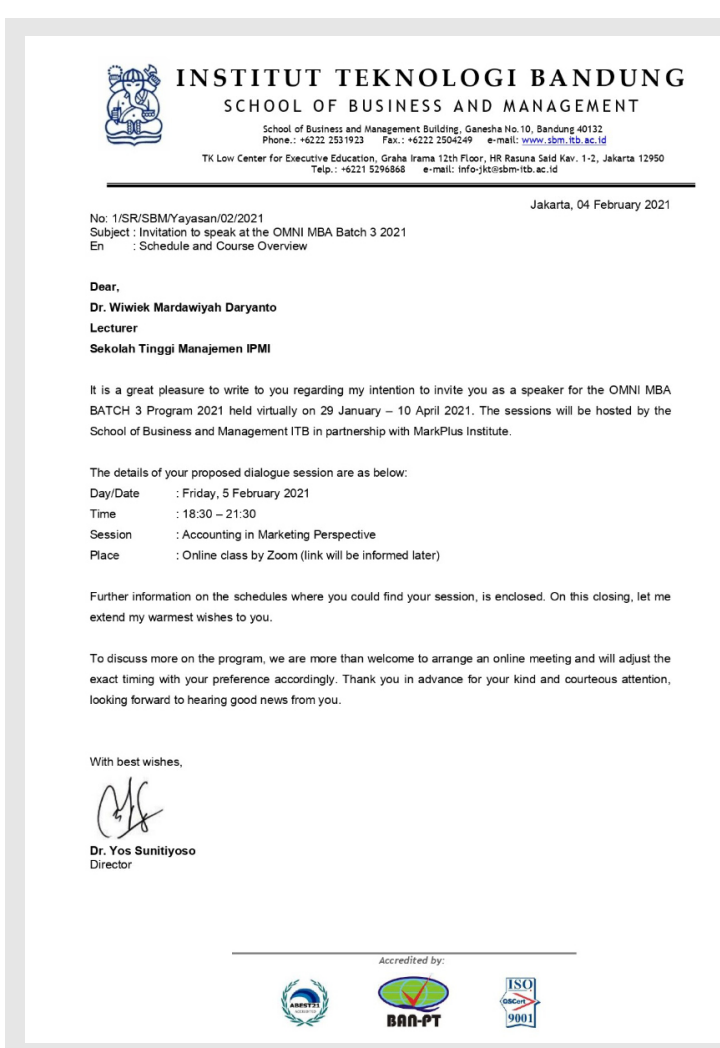

Picture 1. Letter of Appointment as Speaker in OMNI MBA Program (Source: Sekolah Bisnis dan ManajemenInstitut Teknologi Bandung (SBM-ITB), 2021)

Table 1. List of Participants for Accounting in Marketing Perspective Training on Friday, February 5, 2021

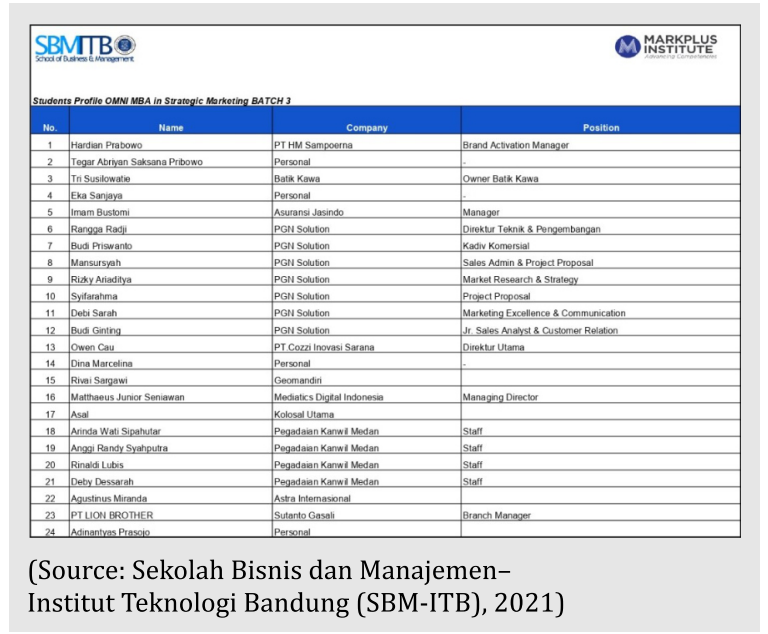

purpose to make economic decisions in line with carrying out management functions. Managerial accounting is defined as an accounting system 
that has the objective of presenting financial and non-financial reports for specific interests for internal parties of the company, for example financial managers, marketing managers, production managers and other internal parties (Anthony, et al., 2011).

\section{Cost Classification}

Despite from being expected to understand financial information through the analysis of the company's financial statements, understanding the cost classification is one of the factors that management must consider in carrying out its functions.

According to Mulyadi (1993), there is a concept of "different cost for different purposes.", which refers as a classification of cost for a specific purpose. The classification of cost according to Mulyadi (2012) is as follows:

Classification of costs on the basis of the object of expenditure.

The classification of costs on the basis of the object of expenditure is divided into three major groups, namely:

a. Cost of raw materials

b. Labor costs

c. Factory Overhead Expenses

Classification of costs based on the main functions of the company (function cost classification).

Classification of costs based on the main functions in which these costs occur are; production costs, general and administrative costs as well as marketing costs.

Classification of costs based on the relationship between costs and something to be financed, or cost object, or cost objective.

In relation to something that is financed, costs can be divided into two groups: direct and indirect costs.

Classification of costs on the basis of time.

On the basis of time, expenses can be divided into two groups, namely capital expenditure and revenue expenditure.
Classification of costs according to their behavior towards changes in the volume of activities.

The classifications are divided into:

a. Variable costs: costs whose total amount changes in proportion to changes in the volume of activities.

b. Semi-variable costs: changes in costs that is not proportional to changes in the volume of activities.

c. Semi-fixed costs: costs that are fixed for a certain volume level of activity and change with a constant amount at a certain volume of production.

d. Fixed costs: costs that total amount is fixed for a given volume level of activity.

\section{Break-Even Point}

Break-even is a condition where the company does not make a profit and does not suffer losses. In other words, a business is said to be Breakeven if the amount of revenue is the same as the total cost, or if the marginal income, which is the difference between sales proceeds and variable costs, can only be used to cover fixed costs.

According to Herjanto (2007), Break-even Point (BEP) is an analysis aims to find certain point in the revenue curve that shows that total costs equal to total revenue. In addition, BEP presents source of information to management in analyzing affecting factors towards the achievement of company profits in the future. There are two ways to determine Break-even, namely Equation Technique and Graphic Approach.

\section{Equation Technique}

Profit refers as sales proceeds minus costs, or it can be expressed in the following equation:

$\mathrm{Y}=\mathrm{cx}-\mathrm{bx}-\mathrm{a}$

Where, $-y=$ profit

$-c=$ selling price per unit

$-\mathrm{x}=$ number of units sold

- $b=$ variable cost per unit

- $\mathrm{a}=$ fixed cost

If the equation is stated in the form of an income statement.

\section{Graphic Approach}




$\begin{array}{ll}\text { Sales } \quad \mathrm{Rp} \quad \mathrm{cx} & \\ \text { Variable costs } & \mathrm{bx}- \\ \text { Marginal income } & \mathrm{Rp} \mathrm{cx}-\mathrm{bx} \\ \text { Fixed costs } & \mathrm{a}- \\ \text { Profit } \quad \mathrm{Rp} & \mathrm{y}\end{array}$

In definition, a company will break-even if the amount of the revenue is equal to the total cost; or (profit $=$ zero, $y=0$ ); or if it is stated as follows:

$$
\begin{aligned}
& 0=c x-b x-a \\
& c x=b x+a
\end{aligned}
$$

The equation is solved as follows:

$$
\begin{aligned}
& c x=b x+a \\
& c x-b x=a \\
& X(c-b)=a \\
& \text { X (BREAK - EVEN })= \\
& \frac{a}{C-\mathrm{b}}
\end{aligned}
$$

Where,

$$
\begin{aligned}
& c x=b x+a-------- \text { sales revenue }=\text { total costs } \\
& c x-b x=a------ \text { contribution } \text { margin }=\text { fixed cost }
\end{aligned}
$$

Hence, Break-even (in product units) is the fixed cost divided by the difference between the selling price per unit and the variable cost per unit. The formula for break-even in sales rupiahs can be found by multiplying the break-even formula by c, which is the selling price per unit of product.

$$
c(\mathrm{x} B E)=\frac{(\mathrm{a}) \mathrm{c}}{c-\mathrm{b}}=\frac{\mathrm{ac}}{\mathrm{c}-\mathrm{b}}=\frac{a}{1-\mathrm{b} / \mathrm{c}}
$$

So the break-even calculation formula in sales dollars, is:

$$
\text { Break Even }(\mathbf{R p})=\frac{a}{1-b / c}
$$

Notes:

1-b/c called the marginal income ratio or margin ratio, which is the quotient of the marginal income and the sales proceeds.

\section{Objectives and Benefits of Training}

The objectives of Accounting in Marketing Perspective at OMNI 2021 MBA Program Batch III training are, as follows:

1. Assist in preparing an effective planning or budget estimate.

2. Operational reference for day-to-day efforts in order to obtain an effective and efficient work system.

3. Assist the supervisory and controlling processes in order to avoid deviations from operational management that are not in accordance with standards, expenditures of business funds that are above budget, errors in work procedures and others.

4. Facilitate the decision-making process related to the resolution of the company's operational problems.

It is hoped that after attending the two sessions of the Accounting in Marketing Perspective training, participants can take advantage of an understanding of Managerial Accounting, including:

1. Budgeting and implementing the company's operating budget.

2. Determination of cost calculation methods and procedures, cost control, accurate costing and continuous quality improvement.

3. 3. Calculate the company's costs and profits for an accounting period, annual, or shorter period

4. Choosing systems and procedures from the best alternatives, in order to increase revenues and reduce costs.

\section{METHODOLOGY}

Accounting in Marketing Perspective Batch III training is conducted via Zoom Meetings from 18:30 to 21: 30 . This training is designed so that students can comprehensively understand the material presented, so that it can be implemented in an applicable way in the world of work. The training methods used by the authors are as follows:

1. Presentation of the material using a power point; and

2. Discussion and settlement of case study questions related to the material presented.

\section{RESULT AND DISCUSSION}

The Accounting in Marketing Perspective Batch III training which conducted for 4 hours and was 
divided into 2 sessions gave the following results:

1. Increase the knowledge and understanding of participants about the importance of understanding Managerial Accounting.

2. Increase the competence and productivity of participants in maximizing their function as company managers.

There are several factors that support the implementation of this training activity, including the great interest and enthusiasm of participants during the training activities, thus, the activity runs smoothly and effectively. In addition, the inhibiting factor is the limited training time. Picture 2 depicts a photo screenshot of the training activity with the twenty-four participants who play an active role in the Accounting in Marketing Perspective training Batch III.

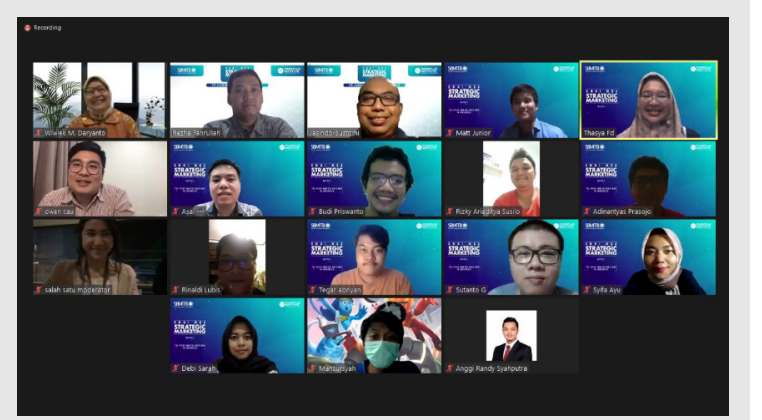

Picture 2. Photos of Training Activities

(Source: Sekolah Bisnis dan

Manajemen- Institut Teknologi Bandung (SBM-ITB), 2021)

Picture 3 depicts the certificate of appreciation from Sekolah Bisnis dan Manajemen - Institut Teknologi Bandung (SBM-ITB) and MarkPlus to the author for the author's role as a facilitator in the Accounting in Marketing Perspective Training on February, 5, 2020.

Tabel 2. depicts the result of participants evaluations of authors in facilitating the Accounting in Marketing Perspective training on February 5, 2021.

Table 2. Results of Training Evaluation of Authors

\begin{tabular}{llcr}
\hline No & Name & Average & Grade \\
\hline 1. & Dr. Wiwiek M. Daryanto & 4.38 & Excellent \\
& SE-Ak, M.M, C.MA & & \\
\hline
\end{tabular}

(Source: Sekolah Bisnis dan

Manajemen- Institut Teknologi Bandung (SBM-ITB), 2021)
Where,

1.00 - 1.80 Poor

1.81 - 2.60 Fair

$2.61-3.40$ Good

$3.41-4.20$ Very good

4.21 - 5.00 Excellent

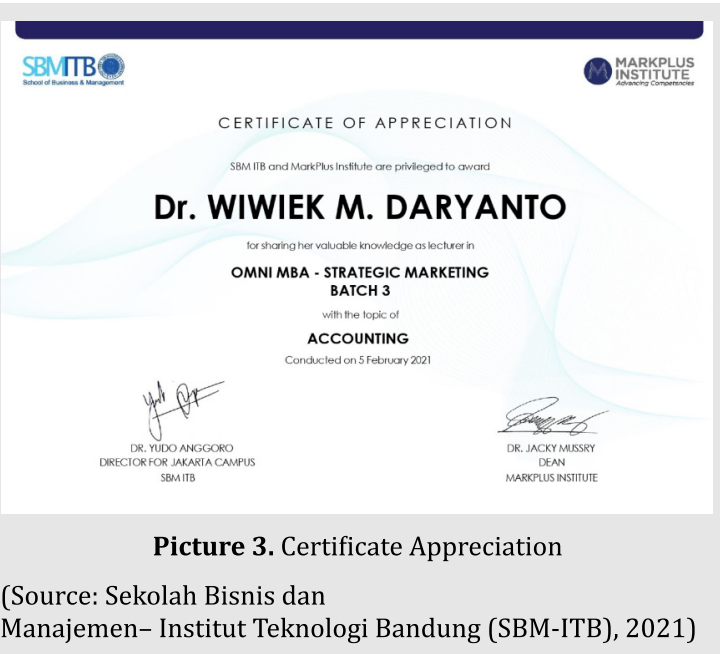

\section{Conclusion and Recommendation}

Based on the above discussion, it can be concluded that Managerial Accounting training for managers, especially in the field of marketing, is important in order to maximize the manager's function of the company.

The understanding of Managerial Accounting managers will help managers to manage their work units or parts effectively by considering the financial aspects of the company. In addition, managers can use the information as reference in developing future plans and make decisions in choosing alternatives and formulating policies.

Given the importance of this, further similar training is needed but in a wider reach such as; perspective from the production function of goods or services. This is due to the need for a strong relationship between marketing and production. These relationships must be harmonious and in line, both in planning and controlling functions. 


\section{DAFTAR PUSTAKA}

Hasibuan, Malayu S.P, 2011. Manajemen Sumber Daya Manusia. Jakarta: PT Bumi Askara.

Herjanto, Eddy. 2007. Manajemen Operasi. Jakarta. Grasindo.

Mulyadi. 1993. Sistem Akuntansi. Edisi Ketiga. Yogyakarta: Sekolah Tinggi Ilmu Ekonomi YKPN.

Mulyadi. 2012. Akuntansi Biaya.Edisi 5.Yogyakarta: UPP STIM YKPN

Robert Newton Anthony, David F. Hawkins, Kenneth A. Merchant. 2011. "Accounting: Text and Cases" Edition 13. McGraw-Hill/Irwin. 